\title{
Quality assessment and primary uses of harvested rainwater in Kleinmond, South Africa
}

\author{
PH Dobrowksy' ${ }^{1}$ D Mannel ${ }^{2}$, M De Kwaadsteniet ${ }^{1}$, H Prozesky $^{3}$, W Khan ${ }^{1 *}$ and TE Cloete ${ }^{1,4}$ \\ 'Department of Microbiology, Faculty of Science, Stellenbosch University, Private Bag X1, Stellenbosch, 7602, South Africa \\ ${ }^{2}$ Water Institute, Stellenbosch University, Private Bag X1, Stellenbosch, 7602, South Africa \\ ${ }^{3}$ Department of Sociology and Social Anthropology, Faculty of Arts and Social Science, Stellenbosch University, Private Bag XI, \\ Stellenbosch, 7602, South Africa \\ ${ }^{4}$ Vice-Rector: Research \& Innovation, Stellenbosch University, Private Bag X1, Stellenbosch, 7602, South Africa
}

\begin{abstract}
With an insightful policy, rainwater harvesting (RWH) can be promoted as a core adaptation strategy for achieving global water security, reaching the Millennium Development Goals (MDGs) and sustaining water resources. The microbial and chemical quality of RWH samples collected from tanks in a sustainable housing development in Kleinmond, South Africa, were monitored. Results indicated that the tank water quality was within all the chemical standards (cations and anions) analysed for potable water. However, the counts of the indicator organisms, for example, total coliforms and Escherichia coli, exceeded the guidelines stipulated by the Department of Water Affairs and Forestry (1996). The microbial analysis results thus indicate that the tank water was not fit for potable use without treatment. A social research project was then conducted to describe, amongst others, the condition of the tank and the users' knowledge of the RWH system. In addition, demographic data, viz., gender, household size and employment status, etc., were gathered in order to provide a socioeconomic background description of the study population. Data were gathered by means of face-to-face interviews with 68 respondents. Generally, RWH was used for washing clothes and for cleaning inside and outside the houses. This study noted that without acceptance and necessary training to maintain and use the tank optimally, it is possible that social development projects, such as the one in Kleinmond, will not be sustainable.
\end{abstract}

Keywords: domestic rainwater harvesting; microbial and chemical quality; social perception; acceptance

\section{INTRODUCTION}

The Department of Water Affairs (DWA) aims to provide all South African citizens with access to basic water and sanitation services by 2014. The provision of potable water to rural communities has been recommended as a priority by the Department for achieving this goal. Rainwater harvesting (RWH) has been earmarked as a short-term intervention to provide water, especially to dispersed settlement areas (DWA, 2009), and in the 2011/12 financial year the DWA installed 8068 RWH tanks in 8 provinces. Of these tanks, 6308 were installed to provide access to a water supply and 1760 tanks were installed for food production (DWA, 2012).

However, possible health risks associated with the consumption of harvested rainwater remain one of the major obstacles hampering the large-scale implementation of RWH systems, as microbial and chemical contaminants have previously been detected in rainwater tanks (Spinks et al., 2006; Sazakli et al., 2007; Lee et al., 2010; Ahmed et al., 2012; Huston et al., 2012). A study in Greece, for example, detected total coliforms, E. coli and enterococci in $80.3 \%, 40.9 \%$ and $28.8 \%$ of the 156 harvested rainwater samples, respectively (Sazakli et al., 2007). Spinks et al. (2006) found that $90 \%, 32.7 \%$ and $73.5 \%$ of 49 samples, collected and analysed in Australia, were contaminated with total coliforms, E. coli and faecal streptococci, respectively. Other

\footnotetext{
To whom all correspondence should be addressed.

Iil +27 21 808-5804; Fax: +27 21 808-5846;

e-mail: wesaal@sun.ac.za

Received 8 August 2013; accepted in revised form 2 May 2014.
}

bacterial pathogens isolated and identified from harvested rainwater samples included Campylobacter spp., Salmonella spp., Cryptosporidium parvum and Giardia lamblia (Abo-Shehada et al., 2004; Ahmed et al., 2008; Ahmed et al., 2010; Ahmed et al., 2012). The primary aim of this study was thus to assess the microbial and chemical quality of harvested rainwater collected from the tanks connected to houses in the Kleinmond Housing Scheme situated in Kleinmond, Western Cape, South Africa. It is, however, important to realise that RWH can only be implemented when people are willing to use it. An additional aim of the study was thus to develop a better understanding of public perceptions, including the degree of acceptance of $\mathrm{RWH}$, and the way in which the harvested rainwater is put to use. More specifically, quantitative and qualitative data were collected in order to describe the following: (i) condition of the tanks; (ii) users' knowledge of the RWH system, including its operation and maintenance; (iii) whether the user would be willing to pay for repairs should the tank break; (iv) perceived benefits and risks associated with RWH; (v) level of satisfaction with RWH; (vi) views on municipal water; and (vii) the purposes for which the rainwater is utilised.

\section{MATERIALS AND METHODS}

\section{Microbial and chemical quality analysis}

\section{Sample site}

The Kleinmond Housing Scheme (Western Cape, South Africa), initiated in 2010 by the Council for Scientific and 


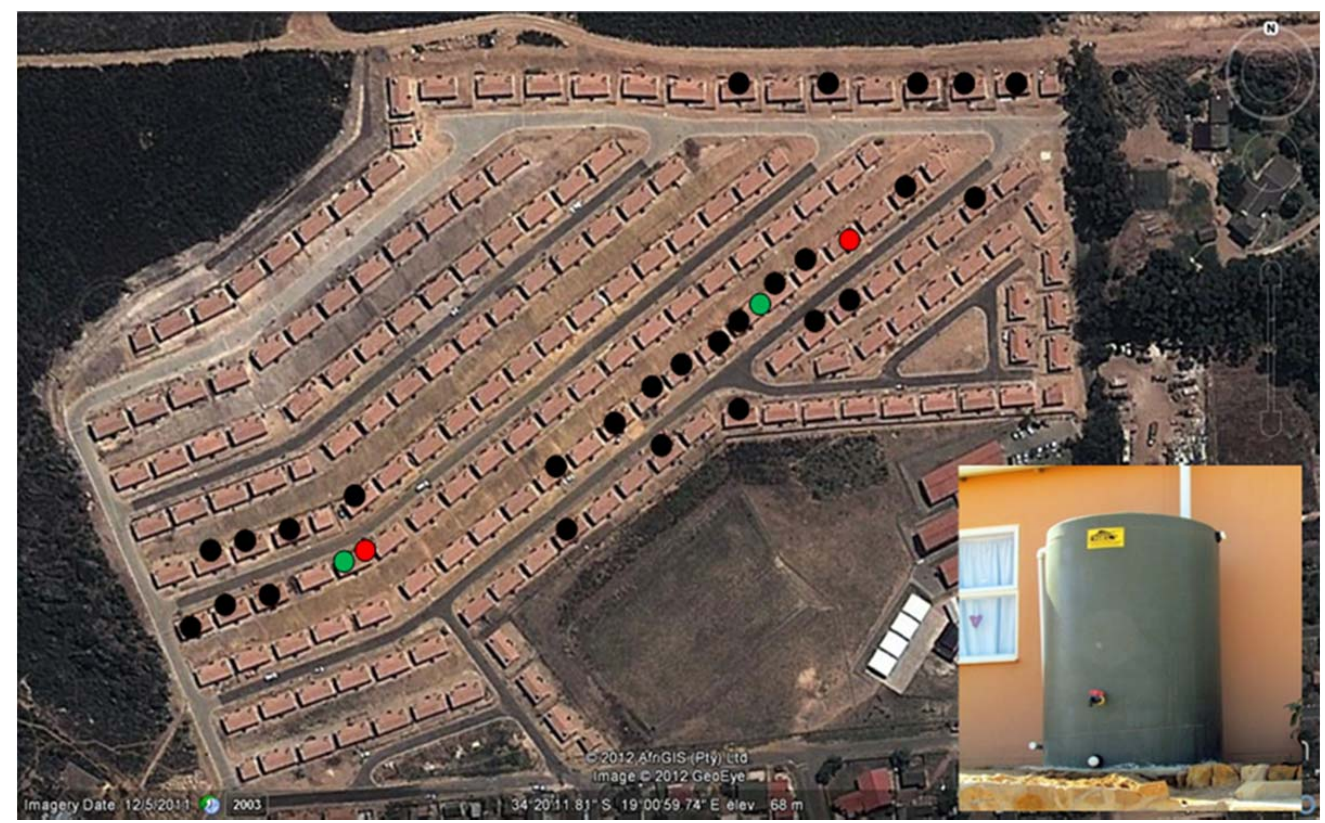

Figure 1

A map of the Kleinmond Housing Scheme (Western Cape, South Africa). The houses selected for sampling throughout the study are indicated by black circles. Green circles indicate the houses that were replaced with alternative, new houses (red circles) that were sampled from the $3^{\text {rd }}$ and $6^{\text {th }}$ sampling sessions.

Industrial Research (CSIR) and the Department of Science and Technology, was used as the sampling site. From a cluster of 411 houses, each fitted with a rainwater tank, 29 houses were randomly selected for sampling rainwater from the tanks during the study period (March to August 2012) (Fig. 1). Sampling was initially conducted every 3 weeks (March to May 2012), and thereafter 1 to 4 days after a rain event (June to August 2012). For microbial and chemical analysis, 232 tank water samples were collected in sterile $2-\ell$ polypropylene bottles over the entire sampling period. The temperature and $\mathrm{pH}$ of the tank water at the sampling locations were measured using a hand-held mercury thermometer and colour-fixed indicator sticks with a $\mathrm{pH}$ range of 0-14 (ALBET ${ }^{\oplus}$, Barcelona, Spain).

\section{Enumeration of total heterotrophic bacteria and faecal indicators}

Various incubation conditions and culture media were used to enumerate E. coli, total coliforms, faecal coliforms, enterococci and total heterotrophic bacteria present in the harvested tank water samples. Each medium was prepared according to the manufacturer's instructions. Total coliform, E. coli and total heterotrophic plate counts were analysed from Sampling Episodes 1 to 8, while faecal coliform and enterococci counts were analysed from the $2^{\text {nd }}$ sampling onwards.

Membrane filtration was used to obtain E. coli and total coliform counts and the procedure was performed in duplicate within $4 \mathrm{~h}$ of sampling. The method consisted of filtering a total of $100 \mathrm{~m} \ell$ of each sample through a sterile GN-6 Metricel $^{\circ}$ S-Pack Membrane Disc Filter (Pall Life Sciences, Michigan, USA) with a pore size of $0.45 \mu \mathrm{m}$ and a diameter of $47 \mathrm{~mm}$. The filters were then incubated on m-Endo Agar (Merck) at $35 \pm 2{ }^{\circ} \mathrm{C}$ for $18-24 \mathrm{~h}$ (USEPA, 2009).

For each of the 232 tank water samples a serial dilution was prepared for the enumeration of faecal coliforms, enterococci and the total heterotrophic plate count. The dilutions were spreadplated onto $\mathrm{mFC}$ agar and Slanetz and Bartley agar (Merck, Biolab, Wadeville, Gauteng) to obtain faecal coliform and enteroocci counts, respectively. The $\mathrm{mFC}$ agar plates were incubated at $44.5 \pm 0.5^{\circ} \mathrm{C}$ for $22-24 \mathrm{~h}$, while the Slanetz and Bartley agar plates were incubated at $36 \pm 22^{\circ} \mathrm{C}$ for $44-48 \mathrm{~h}$. The total heterotrophic bacteria were enumerated through the pour plate method using Nutrient Agar (NA) (Merck) and then incubated at $37^{\circ} \mathrm{C}$ for $18-24 \mathrm{~h}$.

\section{Chemical analysis}

Metal and anion concentrations were determined for the first sampling session. For the determination of the metal concentrations, Falcon $^{\text {nx }} 50 \mathrm{~m} \ell$ high-clarity polypropylene tubes containing polyethylene caps were pre-treated with $1 \%$ nitric acid before sampling. Metal concentrations were determined using inductively coupled plasma atomic emission spectrometry (ICP-AES), according to Saleh et al. (2000), and nitric acid digestion. High-performance ion chromatography (HPIC) was used to determine the concentrations of the anions, chloride $(\mathrm{Cl})$, nitrate $\left(\mathrm{NO}_{3}\right)$ and sulphate $\left(\mathrm{SO}_{4}\right)$. All chemical analyses were performed at the Central Analytical Facility (CAF), Stellenbosch University.

\section{Social perception study}

The local municipality in Kleinmond was approached to assist in gaining access to the community. The municipal manager provided the researcher with useful information, such as the fact that the community is equally divided between Afrikaansand Xhosa-speakers. A translator conducted the interviews with the Xhosa-speaking respondents.

The research was conducted in accordance with the Framework Policy for the Assurance and Promotion of Ethically Accountable Research at Stellenbosch University (2009). The researcher applied to Stellenbosch University's Research Ethics Committee: Human Research (Humanities) for ethical clearance (protocol number: HS850/2012), which was provided before fieldwork commenced.

\section{Sampling method for data collection}

A sampling frame was constructed from a map of the study 
area which was provided by the municipality. Every house on the map was numbered, and a systematic random sampling technique was applied to select every fifth house on the sampling frame. A total of 68 households were therefore sampled with the objective of interviewing 1 respondent per household by means of face-to-face interviews.

The interviews were guided by a semi-structured questionnaire, and were conducted over a period of 3 days (11-13 September 2012) by the researcher. Although self-administered questionnaires would have been less time-consuming, administering the questionnaire during interviews ensured that the questions were understood by the respondents and thereby increased the accuracy and reliability of the data collected. The collected data were captured, processed and analysed with IBM SPSS Statistics (v. 19).

The questionnaire (English, Afrikaans and Xhosa) was designed to gather primarily quantitative data, but included open-ended questions that delved deeper into the reasons for certain responses. Numerical codes were assigned to the response options for closed-ended questions to simplify data entry and analysis. The translator's involvement increased the Xhosa-speaking respondents' willingness to participate, and facilitated the accurate and reliable administration of questionnaires to these respondents.

The aim of the first section of the questionnaire was to gain an overview of the tanks' condition, and the respondents' knowledge on maintenance. The second part of the questionnaire aimed at probing the use of harvested water. The respondents in Kleinmond where questioned specifically as to whether they use the harvested rainwater for gardening, cooking, drinking, washing clothes, cleaning the house and/or bathing. In answering this question, the respondents could choose more than one option (i.e. as many as apply). The last section focused on the demographic details of the respondents. Respondents' level of concern about water availability was also determined by using a scale, as the answer choices are rank-ordered and have differences in intensity. It should be remembered that surveys cannot measure social action, but can only collect self-reported information of recalled passed action or of prospective action (Babbie et al., 2001).

\section{RESULTS AND DISCUSSION}

\section{Microbiological quality of harvested rainwater}

An average for each of the sampling episodes and for each indicator group is indicated in Table 1 . The drinking water guidelines, as stipulated for each indicator organism by the South African National Standards (SANS)(2005), the World Health Organisation (WHO, 2011), the South African Water Quality Guidelines for Domestic Water Use of the Department of Water Affairs and Forestry (DWAF, 1996) and the Australian Drinking Water Guidelines (ADWG) (NHMRC and NRMMC, 2011) are also listed in Table 1.

\section{Total coliforms and Escherichia coli numbers obtained for RWH samples}

For the first two sampling episodes, the numbers of total coliforms could not be distinguished as the samples were filtered undiluted through the membranes. Consequently, the filters were overgrown with bacteria and the values were recorded as Too Numerous To Count $(\mathrm{TNTC}=>250 \mathrm{CFU}$ for undiluted samples). For statistical analysis a figure of $5 \times 10^{3} \mathrm{CFU} / 100 \mathrm{m \ell}$ was assigned as TNTC. From the $3^{\text {rd }}$ sampling onwards, a 1:4 dilution was performed and coliform numbers were established in most samples.

During the first two sampling episodes, all of the rainwater samples collected from the 29 tanks exhibited total coliform numbers above the standards required by DWAF (1996). During Sampling Episodes 3, 4, 5, 6, 7 and 8, 97\%, $79 \%, 100 \%, 100 \%, 100 \%$ and $97 \%$ of the tank water samples, respectively, exceeded the DWAF (1996) guidelines. Overall, $96 \%$ of the tank water samples exhibited total coliform counts above the stipulated guidelines during the entire study period (Table 1).

Escherichia coli counts during Sampling Episodes 1 to 4 (even after a 1:4 dilution) could not be distinguished from the total coliform numbers, as dense bacterial growth was observed on the filters (Table 1). Only the last 4 sampling episodes' results will thus be discussed (Fig. 2). The highest E. coli counts

\begin{tabular}{|c|c|c|c|c|c|}
\hline \multicolumn{6}{|c|}{$\begin{array}{c}\text { TABLE } 1 \\
\text { Comparison of indicator organism averages obtained from Sampling Episodes } 1 \text { to } 8 \text { at the Kleinmond Housing Scheme to } \\
\text { drinking water standards }\end{array}$} \\
\hline Source & $\begin{array}{l}\text { Heterotrophic } \\
\text { counts (CFU/100 me) } \\
\text { (SD) }\end{array}$ & $\begin{array}{l}\text { Total coliforms } \\
\text { (CFU/100 m } \ell \text { ) (SD) }\end{array}$ & $\begin{array}{c}E . \text { coli } \\
\text { (CFU/100 m } \ell \text { ) (SD) }\end{array}$ & $\begin{array}{l}\text { Faecal coliforms } \\
\text { (CFU/100 m } \ell \text { ) (SD) }\end{array}$ & $\begin{array}{c}\text { Enterococci } \\
\text { (CFU/100 m } \ell \text { ) (SD) }\end{array}$ \\
\hline Sampling 1 & $6.8 \times 10^{4} \pm 7 \times 10^{4}$ & $5 \times 10^{3} \pm 0$ & $5 \times 10^{3} \pm 0$ & - & - \\
\hline Sampling 2 & $1.4 \times 10^{5} \pm 1.5 \times 10^{5}$ & $5 \times 10^{3} \pm 0$ & $5 \times 10^{3} \pm 0$ & $7 \times 10^{1} \pm 2.6 \times 10^{2}$ & 0 \\
\hline Sampling 3 & $1.2 \times 10^{5} \pm 1.7 \times 10^{5}$ & $6 \times 10^{2} \pm 4 \times 10^{2}$ & $5 \times 10^{3} \pm 0$ & $2.2 \times 10^{4} \pm 7.6 \times 10^{3}$ & $1 \times 10^{2} \pm 5.6 \times 10^{2}$ \\
\hline Sampling 4 & $4.6 \times 10^{5} \pm 2.1 \times 10^{6}$ & $3 \times 10^{2} \pm 3.8 \times 10^{2}$ & $5 \times 10^{3} \pm 0$ & $5.2 \times 10^{3} \pm 6.9 \times 10^{2}$ & $9 \times 10^{2} \pm 2.1 \times 10^{3}$ \\
\hline Sampling 5 & $5.9 \times 10^{4} \pm 1.7 \times 10^{5}$ & $13 \times 10^{2} \pm 9 \times 10^{2}$ & $6 \times 10^{1} \pm 6 \times 10^{1}$ & $8 \times 10^{3} \pm 2.1 \times 10^{3}$ & 0 \\
\hline Sampling 6 & $3 \times 10^{5} \pm 2.6 \times 10^{5}$ & $9 \times 10^{2} \pm 2.9 \times 10^{2}$ & $4 \times 10^{1} \pm 2.3 \times 10^{1}$ & $2.5 \times 10^{3} \pm 4.6 \times 10^{3}$ & 0 \\
\hline Sampling 7 & $1.3 \times 10^{5} \pm 4.2 \times 10^{5}$ & $8 \times 10^{2} \pm 3.7 \times 10^{2}$ & $3 \times 10^{1} \pm 2.7 \times 10^{1}$ & $2.5 \times 10^{3} \pm 5.7 \times 10^{3}$ & $1.4 \times 10^{2} \pm 5.2 \times 10^{2}$ \\
\hline Sampling 8 & $4.3 \times 10^{5} \pm 1.4 \times 10^{6}$ & $8 \times 10^{2} \pm 8.9 \times 10^{2}$ & $8 \times 10^{1} \pm 4.2 \times 10^{2}$ & $1.2 \times 10^{3} \pm 2.5 \times 10^{3}$ & $2.1 \times 10^{2} \pm 7.7 \times 10^{2}$ \\
\hline SANS 241 (SABS, 2005) & - & - & 0 & 0 & - \\
\hline WHO (2011) & - & - & 0 & 0 & - \\
\hline DWAF (1996) & $<10000$ & $\leq 5$ & 0 & 0 & - \\
\hline $\begin{array}{l}\text { ADWG (NHMRC and } \\
\text { NRMMC, 2011) }\end{array}$ & $\mathrm{D}^{*}$ & $\mathrm{D}^{*}$ & 0 & 0 & 0 \\
\hline
\end{tabular}

$D^{*}$ The Australian Drinking Water Guidelines do not indicate a recommended value but do indicate that numbers should be established on a systemspecific basis and increased numbers should be investigated. 


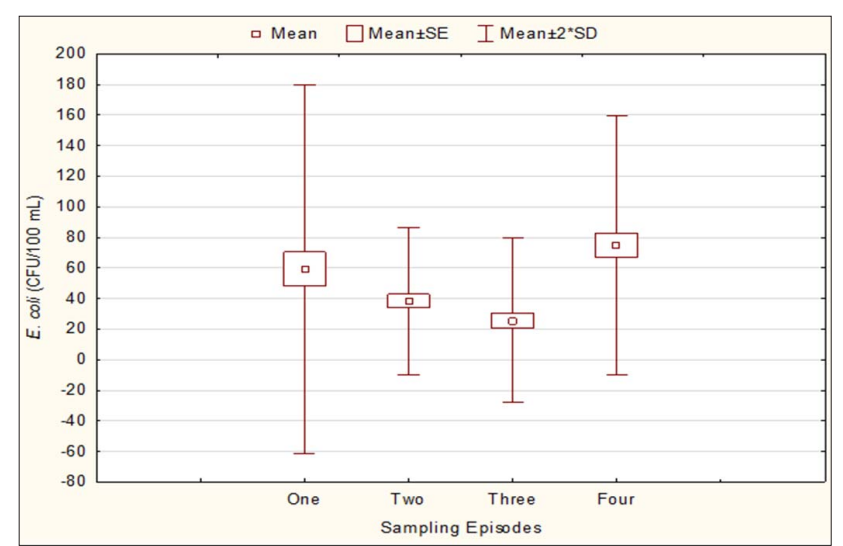

Figure 2

Enumeration of E. coli numbers (CFU/100 ml) in the tank water samples (Kleinmond) obtained for Sampling Episodes 5 to 8 utilising membrane filtration technique ( $m$-Endo agar)

utilising the membrane filtration technique were obtained for Sampling Episode $8\left(8 \times 10^{1} \mathrm{CFU} / 100 \mathrm{~m} \ell\right)$, where $100 \%$ of the samples exceeded the stipulated guidelines (Table 1), while the lowest counts were obtained for Sampling Episode $7\left(3 \times 10^{1}\right.$ CFU/100 ml), where $93 \%$ of the RWH tanks sampled exceeded the E. coli guidelines (Table 1). Overall, for Sampling Episodes 4 to $8,95 \%$ of the tanks sampled exceeded the recommended E. coli count of $0 \mathrm{CFU} / 100 \mathrm{ml}$.

\section{Enterococci}

During the $2^{\text {nd }}, 5^{\text {th }}$ and $6^{\text {th }}$ sampling episodes, all of the tank water samples collected from Tanks 1 to 29 adhered to drinking water standards, with no enterococci detected (Table 1). However, during Sampling Episodes 3 and 4, 3.4\% and 34.5\% of the tank water samples exceeded the specified enterococci drinking water guideline count, while during Sampling Episodes 7 and 8, 6.9\% and $10.3 \%$ of the samples exceeded the enterococci standards, respectively. Overall, on average $7.9 \%$ of the rainwater tanks sampled from March to August 2012 had elevated numbers of enterococci present.

\section{Faecal coliforms}

Faecal coliform numbers enumerated during Sampling Episodes 2, 3, 4, 5, 6, 7 and 8 showed that $6.9 \%, 34 \%, 41 \%$, $34 \%, 55 \%, 52 \%$ and $41 \%$, respectively, exceeded the various drinking water guidelines as indicated in Table 1. This study also showed that, overall, $37.9 \%$ of the rainwater tanks contained elevated faecal coliform numbers (numbers above the standards).

\section{Heterotrophic plate count (HPC)}

During the first sampling episode, $89.7 \%$ of the tank water samples exceeded the standards stipulated by DWAF (1996) for HPC. In addition, the percentages of tank water samples where the HPC number exceeded the acceptable levels, as stipulated by the respective guidelines, for the $2^{\text {nd }}, 3^{\text {rd }}, 4^{\text {th }}, 5^{\text {th }}$, $6^{\text {th }}, 7^{\text {th }}$ and $8^{\text {th }}$ sampling episodes, were $96.5 \%, 65.5 \%, 82.8 \%$, $37.9 \%, 100 \%, 89.6 \%$, and $65.5 \%$, respectively. Overall, for the duration of the sampling period (March to August 2012), $78 \%$ of the tank water samples exceeded the DWAF (1996) guidelines.

\section{Rainfall and chemical analysis}

In total, 8 sampling episodes were conducted for the duration of the study with a total rainfall recorded for each month (Table 2). The overall rainfall patterns recorded for Kleinmond during the sampling period were obtained from the South African Weather Service (2012). The total monthly rainfall (mm) observed for Sampling Episodes 1 to 4 (ranging from 16.8 $\mathrm{mm}$ in March to $30.6 \mathrm{~mm}$ in May) was lower than for Sampling Episodes 5 to 8 (ranging from $74.7 \mathrm{~mm}$ in June to $198.1 \mathrm{~mm}$ in August). No significant difference $(p>0.05)$ was observed between the rainwater samples collected from the 29 tanks in terms of temperature and $\mathrm{pH}$ levels, during the entire sampling period.

\begin{tabular}{|l|l|l|}
\hline \multicolumn{3}{|c|}{ TABLE 2} \\
$\begin{array}{c}\text { Dates of sampling episodes and rainfall recorded } \\
\text { for each of the corresponding months }\end{array}$ \\
\hline $\begin{array}{l}\text { Sampling } \\
\text { Episode }\end{array}$ & Date (2012) & Rainfall (mm) \\
\hline 1 & 05-Mar & 16.8 \\
\hline 2 & 28-Mar & 16.8 \\
\hline 3 & 19-Apr & 56.5 \\
\hline 4 & 22-May & 30.6 \\
\hline 5 & 05-Jun & 74.7 \\
\hline 6 & 19-Jun & 74.7 \\
\hline 7 & 07-Aug & 198.1 \\
\hline 8 & 21-Aug & 198.1 \\
\hline
\end{tabular}

Various anions and metal cations were analysed for during the first sampling episode. Amongst others, lithium, beryllium and tin were not detected in the 29 tank water samples collected during the first sampling episode. However, lithium (7.31 $\mu \mathrm{g} / \ell)$ was detected in the control sample. All other anions and metal cations analysed were within the DWAF (1996), SANS 214 (SABS, 2005) and ADWG (NHMRC and NRMMC, 2011) drinking water guidelines.

\section{Social perception study}

Of the 68 respondents interviewed, the majority (52 respondents, or 76\%) were female, while only 16 respondents were male. When questioned on the condition of the RWH tank, 78\% of the respondents reported that their RWH tanks were in what they perceived to be a good condition. The remaining $22 \%$ of the respondents experienced problems related to leaking tanks, or missing lids or broken pipes or taps. Almost all users preferred to retain the tank. They motivated their preference by referring to benefits associated with the tank, particularly in terms of saving money (22 respondents), as municipal water is expensive. The second-most common reason for wanting to keep the tank relates to their experience of not receiving municipal tap water due to maintenance and repairs (16 respondents) (which was the case during the data collection period). During such disruptions in municipal water provision, in particular, the tank becomes a convenient asset. Ninety percent also indicated that they would not sell the tank, while $66 \%$ would pay money to fix their tank when required, $18 \%$ would not pay and $16 \%$ are unsure if they would pay to fix the tank. In Kleinmond, approximately half of the respondents also acknowledged that they would not know what to do if the tank 
broke and $90 \%$ responded that they would like to learn how to maintain the tank.

When questioned on the access to and management of water, $43 \%$ of the respondents stated that they use the water on a daily basis, $40 \%$ utilised the rainwater a few times a week, $15 \%$ used the harvested rainwater less often than weekly and $3 \%$ never used the harvested rainwater. The major use for harvested rainwater in this community is to wash their clothes. The second-most common purpose for which the rainwater is used is general cleaning, such as cleaning the house, cars, etc. A few gardens were watered with the rainwater (Table 3). It should be noted however, that approximately two-thirds $(68 \%)$ of the respondents do not use the water in the tank for drinking, while by far the majority of those who use it for drinking, do so only sometimes $(24 \%)$.

\begin{tabular}{|l|c|c|}
\hline \multicolumn{3}{|c|}{ TABLE 3} \\
$\begin{array}{l}\text { Primary application and uses of the rainwater as indicated } \\
\text { by the respondents in the Kleinmond Housing Scheme }\end{array}$ \\
\hline $\begin{array}{l}\text { Do you use the rainwater for } \\
\text { the following? }\end{array}$ & $\mathbf{n}$ & $\%^{*}$ \\
\hline Laundry & 62 & 92 \\
\hline Cleaning & 47 & 70 \\
\hline Gardening & 31 & 46 \\
\hline Bathing & 30 & 44 \\
\hline Drinking & 16 & 24 \\
\hline Cooking & 13 & 19 \\
\hline
\end{tabular}

${ }^{*}$ Respondents were able to choose more than 1 option; therefore the sum of the percentages will not add up to 100.

Respondents' level of concern about water availability was also determined. When interpreting the results, it is important to take into account that, at the time of data collection, respondents were not receiving running water from the municipality, which could have increased their level of concern about a lack of water. The two households who did not have a tank both confirmed that they had to ask their neighbours for rainwater, and expressed concern about the length of time it would take the municipality to restore tap water provision. The results for the sample as a whole depicted that more than one-third (35\%) of the respondents are often concerned about water availability, and approximately a quarter $(26 \%)$ are sometimes concerned about access to water on a daily basis (Fig. 3).

\section{CONCLUSIONS}

Overall, the results obtained for the chemical analysis section for the 29 rainwater tanks in the Kleinmond Housing Scheme, for the sampling period March to August 2012, indicated that the rainwater quality was within potable chemical standards. While the chemical quality of the rainwater was generally within the stipulated drinking water guidelines, in contrast the results obtained for microbial analysis often significantly exceeded $(p<0.05)$ the guideline standards. The results for total coliforms, Escherichia coli and the heterotrophic plate count fluctuated throughout the study period, with high standard deviation values recorded (March to August 2012). With the exception of a few samples, overall the results recorded significantly exceeded $(p<0.05)$ the stipulated standards. However, only $8 \%$ and $38 \%$ of the samples did not adhere to the guidelines for enterococci and faecal coliforms, respectively, throughout the study period (DWAF, 1996; NHMRC and NRMMC, 2011; WHO, 2011).

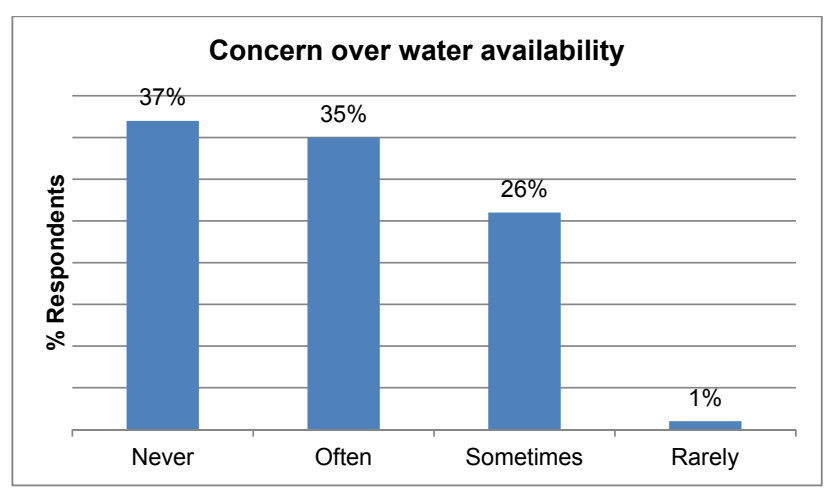

Figure 3

Respondents level of concern about water availability

Based on the counts obtained for all of the indicator organisms, on average, harvested rainwater, that has been stored in polyethylene tanks for a short period of time (> 1 year), is not suitable for drinking purposes as per standards stipulated by the DWAF (1996), the WHO (WHO, 2011) and the ADWG (NHMRC and NRMMC, 2011). Treatment of the harvested rainwater is therefore required before the stored water can be utilised for drinking and certain other domestic purposes.

From the social perception study results it can be concluded that, generally, RWH enjoys a high level of acceptance among the community members in Kleinmond, who tend to use the harvested rainwater for washing clothes and for general cleaning inside and outside their houses. However, maintenance of a rainwater harvesting system is an on-going regular duty and knowledge gaps in terms of maintaining the tank exist, as approximately half of the respondents acknowledged that they would not know what to do if the tank broke. In addition, even though some of the respondents would boil the rainwater before drinking and cooking with it, it is possible that these users are not aware of the extent to which common sources of rainwater contamination, such as dirt and faeces which come mainly from birds and small animals on the roof surface and which flow into the tank, may pollute the water (Worm and Van Hattum, 2006). Several sources of literature (Ward et al., 2007; Mwenge Kahinda et al., 2007; Domenech and Sauri, 2011) thus emphasise the importance of training, education and awareness creation to encourage the user's acceptance of RWH.

A training programme is recommended to fill the knowledge gap and empower users by providing them with information. Such training should include the reasons why RWH is important, awareness as to why they received the tanks and how the tanks are meant to benefit them if they use them correctly, the potential contamination of rainwater, the health risks involved and how to minimise these, especially if they opt to utilise rainwater for drinking and cooking. An alternative solution may be to train 1 or 2 individuals in the community to supervise the functioning, operation, maintenance and repair of the tanks, instead of rolling out a training programme geared at the entire household.

\section{ACKNOWLEDGEMENTS}

The authors would like to thank the following persons and institutions: the Water Research Commission and the National Research Foundation for funding this project; Mr. Joseph Smith and the Kleinmond Municipality, for their assistance. 


\section{REFERENCES}

ABO-SHEHADA M, HINDYIA M and SAIAH A (2004) Prevalence of Cryptosporidium parvum in private drinking water cisterns in Bani-Kenanah district, northern Jordan. Int. J. Environ. Health Res. 14 (5) 351-358.

AHMED W, GOONETILLEKE A and GARDNER T (2010) Implications of faecal indicator bacteria for the microbiological assessment of roof-harvested rainwater quality in Southeast Queensland, Australia. Can. J. Microbiol. 56 (6) 471-479.

AHMED W, HODGERS L, SIDHU JPS and TOZE S (2012) Fecal indicators and zoonotic pathogens in household drinking taps fed from rainwater tanks in Southeast Queensland, Australia. Appl. Environ. Microbiol. 79 (12) 3762-3769

AHMED W, HUYGENS F, GOONETILLEKE A and GARDNER T (2008) Real-Time PCR detection of pathogenic microorganisms in roof-harvested rainwater in Southeast Queensland, Australia. Appl. Environ. Microbiol. 74 (17) 5490-5496.

BABBIE E, MOUTON J, PAYZE C, BOSHOFF N, VOSTER J and PROZESKY HE (2001) The Practice of Social Research. Oxford University Press, Cape Town.

DWAF (DEPARTMENT OF WATER AFFAIRS AND FORESTRY, SOUTH AFRICA) (DWAF) (1996) South African Water Quality Guidelines (2 ${ }^{\text {nd }}$ edn.) Volume 1: Domestic Water Use. CSIR Environmental Services, Pretoria.

DWA (DEPARTMENT OF WATER AFFAIRS, SOUTH AFRICA) (2009) URL: http://www.dwa.gov.za/WFGD/documents/WFGD Frameworkv7.pdf (Accessed 29 May 2013).

DWA (DEPARTMENT OF WATER AFFAIRS, SOUTH AFRICA) (2012) Annual Report, 1 April 2011-31 March 2012. URL: http:// www.dwaf.gov.za/documents/AnnualReports/DWA\%20AR\%20 2011-12\%20Reduced.pdf (Accessed 28 May 2013).

DOMENECH L and SAURI D (2011) A comparative appraisal of the use of rainwater harvesting in single and multifamily buildings of the Metropolitan Area of Barcelona (Spain): social experience, drinking water savings and economic costs. J. Clean. Prod. 19 (6-7) 598-608.

FRAMEWORK POLICY FOR THE ASSURANCE AND PROMOTION OF ETHICALLY ACCOUNTABLE RESEARCH AT STELLENBOSCH UNIVERSITY (2009) URL: http://www.warima. org/site media/warima/CONTENT_files/SU Research_Ethics Policy Mar09.doc (Accessed 28 March 2013).

HUSTON R, CHAN YC, CHAPMAN H, GARDNER T and SHAW G (2012) Source apportionment of heavy metals and ionic contaminants in rainwater tanks in a subtropical urban area in Australia. Water Res. 46 (4) 1121-1132.

LEE JY, YANG JS, HAN M, and CHOI J (2010) Comparison of the microbiological and chemical characterization of harvested rainwater and reservoir water as alternative water resources. Sci. Total Environ. 408 (4) 896-905.

MWENGE KAHINDA J, TAIGBENU AE and BOROTO JR (2007) Domestic rainwater harvesting to improve water supply in rural South Africa. Phys. Chem. Earth. 32 (15-18) 1050-1057.

NHMRC \& NRMMC (2011) Australian Drinking Water Guidelines. Paper 6. National Water Quality Management Strategy 2011. National Health and Medical Research Council, National Resource Management Ministerial Council Commonwealth of Australia, Canberra.

SALEH MA, EWANE W, JONES J and WILSON BL (2000) Monitoring Wadi El Raiyan lakes of the Egyptian desert for inorganic pollutants by ion-selective electrodes, ion chromatography and inductively coupled plasma spectroscopy. Ecotox. Environ. Saf. 45 (3) 310-316.

SAZAKLI E, ALEXOPOULOS A and LEOTSINIDIS M (2007) Rainwater harvesting, quality assessment and utilization in Kefalonia Island, Greece. Water Res. 41 (9) 2039-2047.

SABS (SOUTH AFRICAN BUREAU OF STANDARDS) (2005) South African National Standard (SANS) 241 for Drinking Water Quality $\left(6^{\text {th }}\right.$ edn.). South African Bureau of Standards, Pretoria.

SPINKS J, PHILLIPS S, ROBINSON P and VAN BUYNDER P (2006) Bushfires and tank rainwater quality: A cause for concern? J. Water Health 4 21-28.

US EPA (UNITED STATED ENVIRONMENTAL PROTECTION AGENCY) (2009) Analytical methods approved for drinking water compliance monitoring under the total coliform rule - National Primary Drinking Water Regulations. U.S. Environmental Protection Agency Office of Water, Washington, DC. 2009.

WARD V (2007) Rainwater harvesting in informal settlements of Windhoek. Appendices Cand D, pp 83-86. BSc dissertation, Worcester Polytechnic Institute, United States. https://www.wpi. edu/Pubs/E-project/Available/E-project-051207-152911/unrestricted/report.pdf (Accessed 28 March).

WHO (WORLD HEALTH ORGANISATION) (2011) Guidelines for Drinking-Water Quality (4th $4^{\text {th }}$ edn.). World Health Organisation, Geneva.

WORM J and VAN HATTUM T (2006) Rainwater Harvesting for Domestic Use. Agromisa Foundation, Digigrafi, Wageningen. 